\title{
O reino Norte-Americano: a Escatologia do Evangelho Social de Rauschenbusch e o Destino Manifesto
}

\author{
Vanderlei Dorneles*
}

\section{Resumo}

Este artigo faz uma leitura de textos do Evangelho Social de Rauschenbusch a partir dos conceitos de texto e sistema da cultura conforme entendidos pela Semiótica da Cultura. O objetivo é verificar que conexões existem entre a visão social do Reino de Deus defendida pelo autor e a ideologia do Destino Manifesto, bastante difundida na cultura norte-americana no final do século XIX. Os encadeamentos linguísticos e conceituais entre esses textos podem indicar que o Evangelho Social incorpora a visão social e política do império norte-americano como parte de sua teologia do Reino de Deus. A concepção de Rauschenbusch, de um reino de natureza social e política, vincula esse projeto religioso às revoluções democráticas em curso no Ocidente nos últimos séculos, mais especificamente ao projeto político e civilizatório da nação norte-americana. Palavras-chave: Evangelho social. Destino manifesto. Rauschenbusch. Escatologia.

\section{The American Kingdom: the Eschatology of Rauschenbusch's Social Gospel and the Manifest Destiny}

\begin{abstract}
This article addresses Rauschenbusch's Social Gospel as from the concepts of text and system of culture as understood by the Semiotics of Culture. The purpose is to verify which connections exist between the social vision of the Kingdom of God as exhibited by this Christian theologian and the ideology of Manifest Destiny widespread in American culture at the end of the 19th century. The linguistic and conceptual links between those texts may indicate that the Social Gospel embodies the social and political vision of the American empire as part of its theology of the Kingdom of God.
\end{abstract}

* Doutor em Ciências pela Escola de Comunicação e Artes (USP) e doutorando em Ciências da Religião pela Universidade Metodista de São Paulo. É docente da Faculdade de Teologia da UNASP-EC. E-mail: vanderlei.dorneles@ucb.org.br. 
Rauschenbusch's conception about a kingdom of social and political nature links this religious project to the democratic revolution current in the West in the last centuries, more specifically to the political and civilizing project of the American nation.

Key-words: Social gospel. Manifest destiny. Rauschenbusch. Eschatology.

\section{El Reino Americano: la Escatología del Evangelio Social de Rauschenbusch y el Destino Manifiesto}

\section{Resumen}

Este artículo hace una lectura de textos del Evangelio Social de Rauschenbusch a partir de los conceptos de texto y sistema de la cultura según entendidos por la Semiótica de la Cultura. El objetivo del estudio es verificar que conexiones hay entre la visión social del Reino de Dios defendida por el autor y la ideología del Destino Manifiesto, bastante difundida en la cultura americana a finales del siglo 19. Las conexiones lingüísticas y conceptuales entre estos textos pueden indicar que el Evangelio Social incorpora la visión social y política del imperio americano como parte de su teología del Reino de Dios. La concepción de Rauschenbusch de un Reino de naturaleza social y política vincula ese proyecto religioso a las revoluciones democráticas en curso en Occidente en los últimos siglos, más específicamente al proyecto político y civilizatorio de la nación americana.

Palabras clave: Evangelio social. Destino manifiesto. Rauschenbusch. Escatología.

\section{Introdução}

O Evangelho Social despertou grande interesse ao longo do século XX, especialmente a visão do Reino de Deus como uma cristianização da sociedade conforme entendida por Walter Rauschenbusch. Nascido em 1861, ele foi professor do Seminário de Teologia de Rochester, Estado de New York, e morreu em 1918. Estudou economia e teologia na Universidade de Berlim e na Inglaterra, e, em 1892, com apoio de amigos, fundou a chamada Irmandade do Reino, com o propósito de promover o Reino de Deus, algo que ele julgava que os cristãos tinham perdido de vista e que se tornou o tema dominante de seus escritos.

Rauschenbusch não cria que Jesus morreu para fazer expiação pelos pecados das pessoas, mas para mostrar o ideal da "substituição do egoísmo pelo amor como a base da sociedade humana" (BAWER, 1997, p. 93). Ao contrário do cristianismo tradicional, para ele o Reino de Deus não consiste em ganhar indivíduos para o céu, mas em transformar a vida na terra em harmonia com o céu. Ao enfatizar a dimensão social, ele atribuía um papel crucial às "decisões humanas no avanço do Reino de Deus" (SMUCKER, 1994, p. 7). O teólogo de Rochester não só considerava que o Reino de Deus 
tem uma dimensão social predominante, mas que estava às portas em seu tempo. Nesse período, os Estados Unidos entravam na modernidade e se transformavam numa potência global, com o crescimento da indústria e do comércio, bem como, da expansão da indústria de armas e do surgimento do cinema. O avanço do capitalismo ocidental e do enriquecimento dos grandes magnatas norte-americanos também ganhava impulso. Esses fatores parecem ter exercido grande influência sobre o pensamento social de Rauschenbusch. Para ele, o Reino de Deus avançaria ou seria comprometido pelas decisões humanas se estas fossem determinadas pelo egoísmo e a ganância.

Rauschenbusch foi contemporâneo do influente clérigo norte-americano Josiah Strong (1847-1916), editor e autor que reivindicou a justiça e combateu os males sociais. Strong apoiava o ideal missionário de que todas as raças poderiam ser erguidas e levadas a Cristo. Era bastante controvertido por causa de suas crenças raciais e por estar "alinhado com os ideais do darwinismo social” (JOHNSON, 2017, p. 375). Strong publicou, em 1885, o célebre livro Our Country, em que defende que a nação norte-americana, descendente de anglo-saxões, não só fora privilegiada por alcançar o pináculo da civilização, mas que lhe cabia o dever de "cristianizar" e "civilizar" o restante do mundo. Considerado também um dos fundadores do Evangelho Social, Strong editou a revista The Gospel of the Kingdom. Ele foi um dos mais importantes autores a propagar o chamado "Destino Manifesto", segundo o qual os Estados Unidos estavam destinados a ampliar seu poder no mundo e a estabelecer o Reino de Deus. Essa ideologia era marcada pela noção da superioridade da raça branca de fé protestante.

Tendo vivido nesse contexto e sendo igualmente um dos fundadores do Evangelho Social, Rauschenbusch dificilmente não incorporaria ao seu pensamento social essas ideias tão predominantes acerca do papel dos Estados Unidos em implantar uma ordem cristã no mundo. Entretanto, apesar de alguns autores relacionarem Rauschenbusch ao Destino Manifesto, é preciso uma atenta consideração sobre a presença dessa ideologia no pensamento desse importante teólogo. De fato, ele (1911, p. 239) afirma que os EUA representam um "crescimento no padrão de vida, e, portanto, um aumento na eficiência física" da humanidade, e que "o rápido progresso" dos Estados Unidos se devia à "riqueza dos recursos naturais, de um lado, mas também ao vigor físico e ao dinamismo mental dos recursos humanos do outro lado".

No contexto atual, em que princípios como inclusão e diversidade estão na ordem do dia, é extremamente necessário revisar visões e conceitos 
religiosos capazes de moldar as sociedades e eventualmente realinhá-los. No início de um novo século, de pretendido predomínio da cultura e política norte-americanas no mundo, é importante revisitar criticamente os fundamentos religiosos desse regime e considerá-los à luz das aspirações por uma sociedade mais justa e culturalmente mais inclusiva. Nesse contexto, o objetivo deste artigo é considerar o pensamento de Rauschenbusch acerca do Reino de Deus e de que forma ele reflete a visão de que os Estados Unidos têm um papel crucial no estabelecimento desse Reino. A hipótese de que os textos de Rauschenbusch podem estar entrecruzados com outros textos sociais de seu tempo é considerada aqui a partir de conceitos oriundos da Semiótica da Cultura.

\section{O sistema da cultura norte-americana}

A leitura dos textos de Rauschenbusch se apoia, portanto, nos conceitos de sistema e texto da cultura conforme entendidos por Iuri Lotman, importante pensador da linguagem. Lotman (1996, p. 23, 24) propõe que a cultura pode ser considerada como "um conjunto de textos distintos e de linguagens entrelaçados uns com os outros". Para Lotman (2000, p. 18), o texto é um reservatório dinâmico de linguagem que conserva, transmite e gera textos. Nessa linha, afirma que, numa dada cultura, os diversos textos narrativos, literários e religiosos se encontram entrelaçados por meio não só de expressões e temas comuns, mas por certos sistemas de linguagem ou visões de mundo que os produtores dos textos necessariamente compartilham. Devido ao papel da memória, os textos dialogam entre si e criam conexões linguísticas e conceituais.

Uma vez que as culturas podem ser estudadas a partir dos sistemas de linguagem ou sistemas culturais que as modelizam, chamamos o sistema em questão de "messianismo americano" (cf. DORNELES, 2011). Um sistema da cultura se apresenta como uma visão de mundo, um modelo de realidade, o qual funciona como uma linguagem secundária essencial para o estudo dos textos dessa dada cultura (LOTMAN, 1978, p. 38, 40). Essa linguagem secundária é encontrada no labirinto dos próprios textos da cultura. A leitura dos textos de Rauschenbusch parte, portanto, da premissa de que, como autor, ele produz seu texto num sistema da cultura no qual uma identidade e um papel históricos já têm sido construídos para a nação norte-americana.

Esse sistema da cultura norte-americana pode ser reportado até aos textos de Fiori, um precursor do conceito de "liberdade" como fundante 
de uma nova ordem social para a humanidade. O místico e filósofo italiano Joaquim de Fiori (1132-1202) teve o mérito de desenvolver uma filosofia da história, dividida em três fases ligadas à trindade cristã: Pai, Filho e Espírito. "Cada um desses períodos mostra, na história, uma nova dimensão da divindade e, assim, capacita para um progressivo aperfeiçoamento da humanidade, alcançando o último estágio, dominado pelo Espírito Santo, a era da liberdade absoluta" (ELIADE, 2000, p. 145). Para Fiori, o estágio terceiro e final seria marcado pela reforma da igreja. Esse conceito de liberdade espiritual foi mais tarde incorporado pela Reforma protestante e a Renascença. De fato, Fiori foi o arauto de um novo regime de liberdade que, segundo Eliade (2000, p. 145), teria sido antecipado se o pensamento dele tivesse recebido atenção mais cedo. A obra de Fiori reflete esse reino da liberdade como uma realização trans-histórica num mundo espiritual, mas também como uma realidade escatológica dentro da própria história (COHN, 1981, p. 108-110). Esta segunda visão ecoa nos textos do Evangelho Social, antes, porém, nos diários de Colombo e em textos da colonização puritana na América.

O descobridor Cristóvão Colombo confessou ter sido influenciado pelo profetismo de Fiori em sua aventura pelo Atlântico. Ele acreditava ter sido escolhido por Deus para dar início ao cumprimento da promessa apocalíptica de "um novo céu e uma nova terra", que ele creu ser a América recém-descoberta, o ponto de partida para o regime da liberdade previsto por Fiori. Colombo acreditava que a descoberta da América era parte dos projetos de Deus para a humanidade. Assim, ele recomendou aos então monarcas espanhóis que somente bons cristãos deviam ser enviados para colonizar esse lado do mundo, escolhido por Deus para ser o "paraíso na terra" (COLOMBO, 1998, p. 158-160). "Vossas Majestades não devem consentir que aqui venha ou ponha o pé nenhum estrangeiro, salvo católicos cristãos.” E justificou: "pois este foi o objetivo e a origem do propósito: que esta viagem servisse para engrandecer e glorificar a religião cristã, não se permitindo a vinda a estas paragens a quem não seja bom cristão" (IBID, p. 71).

Mais tarde, Francis Bacon (1999, p. 223) deu eco a essa visão em sua obra fictícia Nova Atlântida. Em linguagem metafórica, ele considerou a colonização da América como uma realização messiânica. A civilização que ele representou na metáfora "Casa de Salomão" teria uma participação crucial na construção do Reino de Deus. Karen Armstrong (2000, p. 70) diz que Bacon estava convencido de que nada poderia impedir a construção de "um glorioso 
futuro para a humanidade" e que "as invenções da ciência encerrariam a miséria humana e inaugurariam aqui na terra o milenar Reino predito pelos profetas". Ela afirma que Bacon comunicou o entusiasmo de uma "nova era" a ser construída na América. Consta que Bacon foi um dos financiadores da colonização britânica no Novo Mundo (OVASON, 2004, p. viii).

As crenças de Fiori e Colombo acerca do reino da liberdade também ecoam nas palavras do colonizador puritano, o inglês John Winthrop. Em 1630, no famoso sermão "Um modelo de caridade cristã", ele afirmava: "O Senhor fará da nossa experiência um exemplo de glória e razão de louvor diante do mundo. Porque seremos como uma cidade sobre uma colina, e todos os olhos do mundo estarão sobre nós" (citado por BELLAH, 1992, p. 13-15). Mais tarde, a declaração de independência também daria eco ao reino da liberdade previsto por Fiori: "Todos os homens são criados iguais" e "são dotados pelo Criador de certos direitos inalienáveis, entre os quais a Vida, Liberdade e busca da Felicidade" (Wikipedia). Armstrong (2000, p. 83) diz que, quando falavam de "liberdade", os líderes revolucionários norte-americanos usavam "um termo que já estava saturado de significado religioso, o qual tinha associações com a graça e a liberdade do evangelho" e que estava ligado a temas como "o Reino de Deus, no qual toda a opressão terminaria, e ao mito de um povo escolhido que se tornaria instrumento de Deus na transformação do mundo".

Em meados do século XVIII, essa visão dos revolucionários norteamericanos acerca do Reino de Deus como um novo regime de liberdade já havia se descolado das tradições bíblicas de um reino espiritual e se apresentava como um projeto de transformação da sociedade em nível global. Ernest Lee Tuveson, em seu clássico Redeemer Nation (1980, p. 1), afirma que há "cerca de três séculos" espalhou-se uma grande esperança a respeito do futuro da humanidade a qual estava centrada "peculiarmente numa nação - a jovem república dos Estados Unidos".

Essa visão de um Reino Divino social e histórico ecoa nos textos do Evangelho Social. O conceito-chave dessa revolução universal de epicentro norte-americano é "liberdade", bastante recorrente em toda a obra de Rauschenbusch. Ele (1914, p. 197) claramente afirma que "a propagação da liberdade é a glória do mundo moderno" e que os Estados Unidos, "nossa própria nação, foi dedicada ao princípio da liberdade desde seu nascimento". Além disso, ele diz que sempre que outra nação busca "quebrar o poder estrangulador da tirania, uma emoção instintiva de simpatia corre em 
nosso povo norte-americano, mostrando que nós não esquecemos nosso chamado divino". Ele diz ainda que "a demanda cristã pelo Reino de Deus na Terra responde ao apaixonado desejo por liberdade", que por sua vez "permeia e inspira o mundo moderno". Para ele, esse é realmente "um desejo de redenção". Por isso, o cristianismo só avançou de fato na história quando alargou o caminho para a "liberdade". Para Rauschenbusch (1914, p. 119), "este desejo mundial de liberdade é o sopro de Deus na alma da humanidade". A liberdade, portanto, como um dom do Espírito, desponta como um dos princípios essenciais para a construção do Reino de Deus.

\section{O reino de Rauschenbusch}

No estudo dos textos de Rauschenbusch, optou-se por uma leitura mais atenta às suas orações publicadas em 1909, embora diversas referências também sejam feitas a outros livros dele. Essa opção se justifica pelo fluxo mais natural de seu pensamento nesse texto. Ele escreve preces por diferentes grupos de pessoas exploradas como crianças, mulheres, empregados e imigrantes, por pessoas em posições de autoridade e influência, como empresários, juízes, legisladores e escritores, mas também por inventores, artistas e professores. Suas orações refletem uma clara consciência da urgência do tempo, um sentimento de se viver numa época decisiva, em que grandes questões espirituais e humanas estão em jogo. Rauschenbusch (1909, p. 9, 11) transparece um evidente pietismo e expressa o propósito do Evangelho Social, que é "transformar nossa concepção do significado do cristianismo". Ele estava convencido de que "precisamos anunciar novos caminhos a Deus para os pés do homem moderno".

O Reino de Deus é o tema central no pensamento de Rauschenbusch, a partir do qual ele constrói sua visão do Evangelho Social. De acordo com ele, a doutrina do Reino, conforme Jesus ensinou, foi substituída pela doutrina da igreja. Por isso, a teologia deve não somente abrir espaço para a doutrina do Reino de Deus, mas precisa atribuir a este um "lugar central e revisar todas as outras doutrinas articulando-as organicamente" com este tema (1917, p. 131). Há diversas razões, segundo ele, para enfatizar o Reino em lugar da igreja: o Reino não é sujeito às armadilhas da igreja; ele pode testar e corrigir a igreja; ele é uma ideologia profética focada no futuro e uma força revolucionária, política e social que enxerga toda a criação como sagrada; e, por fim, o Reino pode ajudar a salvar a ordem social (1917, p. 134-137). A igreja é primariamente um “ajuntamento para adoração", portanto, é estática; mas “o Reino é um 
ajuntamento para a justiça" (1917, p. 134), por isso, é dinâmico. A compreensão da dimensão social do Reino é predominante no pensamento do "profeta social de Rochester" (SMUCKER, 1994, p. 39). Rauschenbusch (1909, p. 18) considera o Reino como resultado de uma "transformação moral e espiritual [nesta ordem] da humanidade", e que a justiça só será cumprida na terra sob o Reino de Deus. O Reino não resulta da expansão da igreja no mundo, ao contrário, a igreja pode ser um obstáculo para o Reino. Agostinho contribuiu para essa inversão de valores com $A$ Cidade de Deus.

De uma perspectiva protestante, Rauschenbusch (1917, p. 135) critica duramente o ideal medieval da supremacia da igreja sobre o Estado, presente na obra de Agostinho. Para ele, isso foi uma consequência lógica de se fazer da igreja o "mais elevado bem sem nenhum padrão ético superior pelo qual prová-la”. Para ele $(1917,132)$, a doutrina medieval da igreja e do papado foi um resultado direto da luta pela "supremacia da igreja" em detrimento do Reino. No entanto, ele entende que a Reforma, igualmente, não trouxe "nenhuma renascença à doutrina do Reino". Porém, um novo impulso para o Reino estaria se manifestando em seu tempo, com o surgimento do Evangelho Social. "O reavivamento presente da ideia do Reino é derivado da combinação da influência dos estudos históricos da Bíblia e do Evangelho Social" (RAUSCHENBUSCH, 1917, p. 133). Ele (1914, 49) afirma que "a Reforma do século 16 foi um renascimento da teologia Paulina, mas a reforma atual é um avivamento do espírito e dos objetivos do próprio Jesus".

Rauschenbusch expressa a convicção de viver num momento decisivo, uma vez que a reforma do Evangelho Social coincidia com as mudanças no mundo pós-revolução norte-americana. Na introdução de Christianity and the Social Crisis (1911, p. xi), ele afirma que "a civilização ocidental está passando por uma revolução social sem paralelo na história em alcance e poder" e que isso era um acontecimento "inevitável". Ele acrescenta que "as revoluções religiosas, políticas e intelectuais dos últimos cinco séculos, que juntas criaram o mundo moderno, tiveram de culminar necessariamente em uma revolução econômica e social como a que está agora diante nós". Assim, a emancipação intelectual, religiosa, política e industrial eram processos pelos quais o Reino de Deus se estabelecia. Rauschenbusch cria que o Reino de Deus vem por meio do "gradualismo evolucionário", dos quais seu tempo era "um dos mais ricos da história" (SMUCKER, 1994, p. 71).

Uma vez que o Reino é de natureza social, sua realização extrapola os limites da atuação da igreja. Ele precisa abarcar a vida humana como um todo. 
Rauschenbusch (1917, p. 144-145) define o Reino como uma "transformação cristã da ordem social". Ele vê o progresso do Reino de Deus no "fluxo da história", bem como, no "conflito de forças econômicas e classes sociais, no surgimento e queda de despotismos e formas de escravidão, na adoção de novos valores de julgamento e de cânones de moral, gosto e sentimento" (1917, p. 146). Cristo colocou em ação as "forças históricas da redenção", e elas realizam seu trabalho na História (1917, p. 147).

Na compreensão tradicional, o Reino espiritual de Deus se opõe ao reino demoníaco, o que para Rauschenbusch não é verdade. Além disso, essa crença tende a ocultar a responsabilidade humana na construção ou na tardança do Reino de Deus. Ele entende que a crença num reino de Satanás pode ter sido absorvida pelos judeus no exílio, pois há poucas referências a Satanás e a espíritos demoníacos no Antigo Testamento. Rauschenbusch (1917, p. 82) vê a crença em Satanás como um "dualismo modificado" aplicado ao monoteísmo judaico. Esse dualismo e a crença no reino de Satanás teriam sido transferidos do judaísmo para o cristianismo e perpetuados pelos cristãos ao longo da História. Ele (1917, p. 84) lamenta que "a crença num reino demoníaco não foi de forma alguma atacada na Reforma" e que a "firme crença de Lutero nos demônios é bem conhecida". Para ele, espíritos demoníacos não são outra coisa senão fruto de imaginação e superstição. "Foi graças ao ceticismo da era do Iluminismo e à chegada da ciência moderna que a humanidade foi salva da fúria dessa teologia equivocada" (RAUSCHENBUSCH, 1917, p. 85). A compreensão de Rauschenbusch $(1917$, p. 87) é de que a crença num reino satânico tende a desviar a atenção da culpa humana pelo mal prevalecente no mundo, dos homens para poderes espirituais imaginários. No entanto, o Evangelho Social é capaz de renovar a ideia do Reino e de libertá-la das superstições e tradições históricas. E isso era algo em curso em seu tempo.

\section{$O$ reino e a modernidade}

Para Rauschenbusch $(1914$, p. 60, 61), o Reino é de natureza social e encontra sua concretização na transformação para a democracia então em curso no Ocidente às portas da modernidade. Para ele, a ideia do Reino de Deus, no pensamento de Jesus, que viera para servir e não para ser servido, já estava "cheia do espírito democrático", porém, "caiu em tempos despóticos e foi moldada em formas monárquicas". Ao elevar o valor da vida e da alma 
humana, "Jesus colocou o fundamento religioso para a democracia moderna e antecipou o desejo pelo espírito moderno".

Nessa perspectiva, o Evangelho Social deita suas raízes nos movimentos de emancipação plantados pelo Iluminismo e tem na "liberdade" seu conceito estruturante. Para Rauschenbusch (1914, p. 88), o século XVIII marcou, de fato, "a adolescência do espírito moderno", pois um "estranho entusiasmo pela democracia e pelos direitos humanos estava no ar". Filósofos como Leibniz, Herder e Kant não mais confinaram a obra salvadora de Deus a Israel ou à igreja, mas viram o Cristo "educando toda a humanidade através das várias instituições humanas" emergentes. Rauschenbusch (1914, p. 89) afirma que a "mente sublime" de Immanuel Kant foi inspirada por grande entusiasmo ao contemplar a possibilidade de uma "comunidade ética, um reino de virtude, no qual a ação correta não seria, como no Estado, devido à coerção, mas à livre devoção de todos". Nesse sentido, o Reino de Deus seria "o bem supremo e o dever maior". Seu cumprimento e realização seriam um dever da raça humana para consigo mesma, o dever de realizar seu destino divino, uma premissa iluminista.

O reavivamento em curso para o Reino, no início do século XIX, portanto, devia-se ao surgimento da mentalidade moderna e democrática, de origem secular e não necessariamente religiosa. Porém, Rauschenbusch (1917, p. 136) diz que onde quer que o movimento pela democracia e justiça social vier a carecer de "um fundo religioso" a ideia do Reino poderia ser perdida de vista. Ao enfatizar essa dimensão social e secular do Reino, Rauschenbusch viu sua realização como resultado de uma "cristianização" da sociedade como um todo, no contexto da democracia ocidental. Ele chega a empregar os verbos "cristianizar", "moralizar", "humanizar" e "democratizar" de forma intercambiável, embora "cristianizar" seja o mais recorrente desses sinônimos. Cristianizar a ordem social, nesse caso, corresponde a abolir os "privilégios injustos" e transformar as "instituições sociais", por isso o Reino vem de "forma gradativa", na história (SMUCKER, 1994, p. 38).

Alguns questionamentos já têm sido levantados nessa visão do Reino como uma realização da cultura norte-americana de origem europeia. Sanders (2011, p. 114) diz que é vital, nesse caso, entender "como esses sinônimos, conectados como foram à ampla tradição eurocêntrica, funcionariam para perpetuar uma ordem social em que a supremacia branca seja o alfa e o ômega da história”. Ele questiona a importância da questão racial "dentro do contexto da noção de Rauschenbusch acerca da democracia cristã como o 
Reino de Deus". Alguns afirmam que Rauschenbusch foi cativado pela cultura vitoriana de seu tempo. Chega-se a dizer que ele usa os termos "Reino de Deus" e "Destino Manifesto" de forma intercambiável (FISHBURN, 1981), o que não parece apropriado, já que a expressão "Destino Manifesto" é quase ausente em seus escritos. Porém, estava claro que "as instituições políticas e culturais norte-americanas eram para Rauschenbusch a primeira manifestação da presença do Reino na história" (LEMASTERS, 1997, p. 10). Dorrien (2011, p. 60) afirma que as falhas do Evangelho Social são amplas. Segundo ele, Rauschenbusch "batizou a ideologia anglo-saxônica do Destino Manifesto e racionalizou o imperialismo americano". Pelikan (1989, p. 324) diz que Rauschenbusch reconheceu que fora impressionado pela noção de "progresso da civilização", o que ele adotou com "otimismo". Por sua vez, LeMasters (1997, p. 14) argumenta que falar, como Rauschenbusch, de "cristianizar a ordem social por meio de reforma econômica e política" é uma repetição do erro de Constantino, que tentou "fundir a igreja e o mundo", comprometendo a identidade particular de cada um e a missão da comunidade de fé.

Assim, um vínculo entre o Reino de Deus na visão do Evangelho Social e a modernidade de epicentro norte-americano parece claro no pensamento de Rauschenbusch, tendo já recebido algumas críticas. No entanto, é preciso considerar de que forma e em que medida o profeta de Rochester considera o papel social e político dos Estados Unidos como decisivo para o estabelecimento do Reino de Deus, e se ele acreditava que essa nação estava cumprindo esse papel ao promover o imperialismo norteamericano no mundo.

\section{$O$ reino e o destino manifesto}

Tendo considerado a dimensão social e política do Reino de Deus na teologia de Rauschenbusch, é preciso indagar se de fato ele acreditava que Deus teria abençoado os Estados Unidos com uma visão histórica e religiosa mais ampla do que todas as demais nações. O emprego das recorrentes expressões "nosso país" (curiosamente o título do livro de J. Strong) e "nossa nação" sugere que Rauschenbusch realmente via seu país como um precursor e mesmo instrumento do Reino de Deus na terra. Ele tanto reflete a superioridade da cultura norte-americana quanto sugere o papel crucial dessa nação em difundir a democracia e realizar uma transformação social do mundo como condição para o Reino. 
Rauschenbusch (1909, p. 58) parece ver o capitalismo norte-americano como um instrumento para a construção do Reino, desde que não seja sucumbido pela ganância. Para ele, o "mundo do trabalho" pode "alcançar e abençoar todas as classes de nossa nação, e edificar para a república do futuro um grande corpo de trabalhadores, de fortes membros, mentes claras, equilibrados em temperamento, felizes no labor, conscientes de sua dignidade e empenhados juntos pela final irmandade de todos os homens". Por causa de sua ênfase na dimensão social e política do Reino, Rauschenbusch vê as indústrias e grandes empresas capitalistas como instrumentos de aperfeiçoamento da natureza humana. Ele (1909, p. 62) diz que os "mestres da indústria [empregadores]" têm "elevada habilidade e conhecimento para erguer os trabalhadores a fim de [lhes] ampliar a independência e o vigor". Os empregadores e homens de negócios exercem um tipo de sacerdócio para o Reino. Ele (1909, p. 65) diz que aos "senhores da indústria e do comércio ... a riqueza e o poder de nosso mundo moderno [lhes] foram entregues" a fim que eles guiem as pessoas para "a nova era da liberdade". Assim, as empresas capitalistas exercem um importante papel no processo de cristianizar o mundo. Ainda sobre empresários e empregadores, Rauschenbusch (1909, p. 63-64, grifos do autor) diz que eles têm "o compromisso de salvar os outros". No entanto, esses homens podem "trair os interesses de seu próprio enriquecimento", e "uma nova tirania" seria assim "implantada na terra que é dedicada à liberdade".

Mais curioso ainda é o elevado conceito que Rauschenbusch tem da posição superior e da função da nação norte-americana. Ele afirma que, quando se considera a longa e dolorosa busca pela liberdade política no mundo, sobressai-se o "destino esplêndido" desta "verdadeira república plantada nesta nossa gloriosa base territorial”. E completa: "Que missão para a liberdade nosso país pode ter em relação a todas as nações!" Ele chega a afirmar que os Estados Unidos têm um "direito de primogenitura entre as nações" (1911, p. 263). Os Estados Unidos, segundo ele (1909, p. 59), podem abençoar as pessoas de outras nações que para ali se dirigem como imigrantes. "Nós nos lembramos das pessoas de outras nações que veem à nossa nação em busca de pão, de um lar e de um futuro." Os americanos, ele recomenda, devem olhar com a compaixão divina para "aqueles que têm sido exauridos e atrofiados pela pobreza e opressão de séculos, e cuja mente tem sido deformada pela superstição e embrutecida pela agonia da revolta". Os colonizadores, diz ele, "cruzaram o oceano no passado", sendo motivo 
de gratidão "toda a paciência e coragem divina com que eles enriqueceram nossa nação".

Rauschenbusch deu grande importância à "revolução" iniciada pelos puritanos. Para ele, o empreendimento deles não foi uma mudança violenta, mas uma "transformação histórica ampla nas convicções fundamentais e na instituição de uma nação". Cada período importante da história não só é marcado por uma mudança religiosa, mas também por causas sociais. Assim, ele vê a Renascença como a dimensão social da Reforma, e a revolução social e industrial como a contrapartida do puritanismo (SMUCKER, 1994, p. 73). Rauschenbusch (1909, p. 59) afirma que os colonizadores (pais peregrinos) "contribuíram para expandir a riqueza e a liberdade de nosso país, e cujos filhos cresceram em estatura e em pensamento, porque nós também somos filhos de imigrantes, que vieram com os corações ansiosos e os pés tremulantes no caminho ocidental da esperança". Ao se referir ao "caminho ocidental da esperança", ele ecoa a mesma crença de Colombo, para quem Deus teria indicado a travessia do Atlântico como o caminho para o paraíso. Assim, Rauschenbusch (1909, p. 125) suplica a Deus "para reavivar em nós o destemido espírito de nossos pais a fim de que possamos completar a obra deles", edificando sobre "a base da democracia deles o firme edifício da comunidade cooperativa, na qual tanto o governo quanto a indústria serão do povo, pelo povo e para o povo".

Rauschenbusch (1909, p. 60) afirma de forma convicta que os Estados Unidos são fonte da esperança para todos os povos. Ainda sobre os imigrantes ele diz: "Em uma nação dedicada à liberdade possam eles não encontrar a antiga opressão e a ganancia mais feroz", mas "sentir aqui o mais puro ar da liberdade e encontrar a manhã radiosa da alegre esperança". Assim, ele indica que a democracia e justiça nos Estados Unidos são o protótipo do Reino de Deus.

Para todos os oprimidos de longe que buscam a liberdade; para todos os amantes das pessoas que se esforçam para quebrar seus grilhões; para todos que acreditam na democracia e no Reino de Deus, faça com que nossa comunidade uma vez mais seja a segura balizadora da esperança e um guia no caminho que leva para a perfeita união da lei e da liberdade (RAUSCHENBUSCH, 1909, p. 60).

Uma interessante prece de Rauschenbusch é feita pelos ociosos. Ele diz que os Estados Unidos são "amplos e clamam por mais trabalhadores", 
ecoando o dito de Cristo de que a "seara é grande", e são necessários mais trabalhadores (Lucas 10:2). Nessa prece, ele (1909, p. 90) reflete claramente sua visão dos Estados Unidos como construtores de um novo mundo, ou do próprio Reino. "À nossa nação como um todo conceda elevada sabedoria a fim de que ela possa criar um mundo no qual ninguém seja forçado a vaguear na escassez nem perambular na luxúria”. A nação norte-americana, nesse caso, não só está sob as bênçãos do Reino, mas cabe a ela a tarefa de construir o Reino no mundo.

A crença do teólogo de Rochester acerca do papel privilegiado dos Estados Unidos chega a sugerir uma relação direta e íntima entre Jesus Cristo e essa nação. Ele (1914, p. 324) diz que o "despertamento social" tem atingido a nação norte-americana e suas igrejas como um todo, trazendo um "novo sentido de fraternidade". "Nessas agitações das forças espirituais de nossa nação nós reconhecemos a voz do Cristo vivo, que é a alma da humanidade, convocando-nos para completar a tarefa da redenção”. A redenção se consuma com a transformação social, na qual as igrejas exercem um importante papel. Nessa base, ele (1909, p. 114, grifos do autor) pede a Deus: "Envia-nos à frente como os desbravadores da humanidade para liderar teu povo na marcha de mais um dia na direção da terra prometida". Aqui ele reflete a ideia da nação norteamericana como "o novo Israel”, que peregrina em direção à Terra Prometida, mas agora liderando o restante do mundo atrás de si.

Nesse contexto, Rauschenbusch emprega uma expressão bastante típica da ideologia do Destino Manifesto: "o guardador de meu irmão”. Esta expressão ocorre originalmente no livro de Strong (1891, p. 210): “o anglosaxão está divinamente encarregado de ser, num sentido peculiar, o guardador de seu irmão". Rauschenbusch $(1909,116)$ diz: "Envie sobre todos nós a convicção de que a ignorância é pecado, e que nós sejamos na verdade o guardador de nosso irmão". O próprio Rauschenbusch, numa menção rara, se refere a Strong, como um visionário do Evangelho Social.

Eu quero pagar um tributo de honra a três homens que foram pioneiros do pensamento social cristão na América vinte e cinco anos atrás: Washington Gladden, Josiah Strong e Richard T. Ely. Estes homens tinham seu pensamento amadurecido quando nós éramos jovens e havia neles um espírito que também nos despertou e nos compele (RAUSCHENBUSCH, 1914, p. 9).

A expressão "Destino Manifesto", rara nos escritos de Rauschenbusch, foi cunhada pelo jornalista John O’Sullivan, em 1845, no jornal Democratic 
O reino Norte-Americano: a escatologia do Evangelho 131 Social de Rauschenbusch e o Destino Manifesto

News, no contexto da guerra norte-americana contra o México, que ele considerou como uma oportunidade de realizar o plano da Providência. Com forte racismo, ele dizia: "O processo que foi cumprido no Norte, de afastar os índios ou aniquilá-los como raça, ainda deve ser cumprido no Sul”. O tabloide de Sullivan (citado por LENS, 2006, p. 166) afirmava que os Estados Unidos tinham "o direito superior que a Providência" lhes outorgara para desenvolver "o grande experimento da liberdade" no mundo.

Outra expressão empregada diversas vezes por Rauschenbusch (1909, p. 122) e que tem um longo histórico na cultura norte-americana é "nossa cidade", a qual ecoa a chamada "cidade sobre a colina", visualizada por John Winthrop. Ainda nas orações, ele diz: "Nós te agradecemos pelos homens e mulheres patriotas do passado cuja devoção generosa ao bem comum tem sido a construção de nossa cidade", e que "nossa própria geração possa construir dignamente sobre a fundação que eles lançaram”. Ele (1909, p. 107) bendiz a Deus "pelas almas inspiradas de todos os tempos que viram ao longe a brilhante cidade de Deus, e pela fé deixaram o benefício do presente para seguir sua visão". Confiante na revolução de seu tempo, ele insiste:

Conceda-nos a visão de nossa cidade, imparcial como ela possa ser: uma cidade de justiça, onde ninguém venha a devorar os outros; uma cidade de plenitude, onde o vício e a pobreza cessarão para sempre; uma cidade de fraternidade, onde todo sucesso será encontrado no serviço, e a honra será outorgada somente aos nobres; uma cidade de paz, onde a ordem não será estabelecida pela força, mas no amor de todos pela cidade, a grande mãe da vida e da felicidade comum (RAUSCHENBUSCH, 1909, p. 122-123).

A “nossa cidade” de Rauschenbusch (1909, p. 124) não é um simples aglomerado de pessoas, mas a "cidade" como designação da própria nação norte-americana. Ele ainda diz: "Ó Deus, nós te louvamos pelo sonho da dourada cidade da paz e da justiça que sempre tem sido visitada pelos profetas da humanidade". Entre esses, estariam os profetas bíblicos bem como aqueles da tradição da liberdade desde Fiori até os puritanos e líderes revolucionários. O reverendo Peter Bulkeley (1583-1659), reiterando a crença de Winthrop, escreveu: "Somos uma cidade sobre a colina, à vista de todos. Os olhos do mundo estão voltados para nós" (1968, p. 123). O ex-presidente norteamericano Ronald Reagan (1981-1989) citou várias vezes John Winthrop e a "cidade sobre a colina". Em 1990, em seu discurso de despedida, ele se referiu ao colonizador: 
Há poucos dias, olhando pela janela, eu pensei numa "brilhante cidade sobre uma colina" - a frase de John Winthrop, que descreveu a América que ele imaginava. ... Ele foi um dos primeiros peregrinos, um dos primeiros homens livres. ... Eu falei da "brilhante cidade sobre a colina" durante toda a minha vida política. ... Nós fizemos a diferença. Nós fizemos a cidade mais forte, nós fizemos a cidade mais livre e a deixamos em boas mãos (citado por JUNQUEIRA, 2001, p. 32-33).

Assim, a teologia do Evangelho Social de Rauschenbusch mostra claras conexões com o pensamento social e político de seu tempo, de forma que seus textos se mostram entrecruzados com outros da cultura norte-americana. A concepção do Reino de Deus como uma transformação ou cristianização da sociedade, sob a liderança da nação norte-americana se apresenta, portanto, como um desdobramento mais cristianizado da ideologia do Destino Manifesto. A partir dessa noção geral do Reino de Deus, Rauschenbusch desenvolve a sua escatologia e sua visão profética. As questões sociais também exercem nesse sentido um papel crucial.

\section{O reino e o império}

Ao se referir a certos símbolos apocalípticos, Rauschenbusch reflete uma compreensão profética mediada pelas questões políticas e sociais. Entretanto, ele parece enxergar a batalha do cristianismo contra as forças opositoras, no estabelecimento do Reino, na mesma perspectiva do cristianismo apostólico e da Reforma. Para ele, as forças opositoras do Reino de Deus ou a favor do mesmo tomam expressão nos impérios globais. Nessa linha de pensamento, ele faz uma comparação entre o contexto norte-americano e a experiência da igreja no Império Romano. Segundo ele, os cristãos dos primeiros séculos estavam convencidos de que era seu papel "assimilar e transformar todos os outros povos em uma unidade superior", numa espécie de protovisão do Evangelho Social. Nisso, ele diz que "a evolução da religião sempre esteve intimamente ligada à evolução da organização social". E completa:

Quando tribos foram amalgamadas em uma nação, religiões tribais passaram a fazer parte de uma religião nacional. No Império Romano as nações estavam agora sendo fundidas em uma unidade social ainda maior. ... Havia uma necessidade de uma religião internacional puramente humana. O cristianismo, como sabemos hoje, estava destinado a cumprir esta função, e 
os primeiros pensadores cristãos tiveram uma visão profética desse destino (RAUSCHENBUSCH, 1911, p. 114).

Para o bem do Reino, os cristãos e o Império Romano deveriam entrar em acordo, pois este era "o propósito manifesto de Deus". Aqui Rauschenbusch reflete a ideia da união entre a igreja e o Estado imperial como caminho para o Reino, o que parece se projetar no caso norteamericano. "O Império deveria deixar de perseguir a igreja, e a igreja poderia ser o melhor aliado do Estado na criação da paz civil, porque os cristãos tinham a moralidade mais elevada e porque só eles tinham poder sobre os demônios que ameaçavam a segurança do Império". Ele argumenta que, no Império Romano, o cristianismo era um "poder penetrante, renovador e unificador, destinado a controlar o futuro do mundo" (RAUSCHENBUSCH, 1911, p. 115). Nisso, o profeta de Rochester evidencia uma clara percepção da dimensão religiosa e política do Reino de Deus em termos de uma união entre a igreja e o Império. No entanto, o Império Romano precisava entender a grande oportunidade provida com a expansão da igreja para que o Reino se difundisse mediante a mútua cooperação. Como isso não ocorreu, e o Império na verdade passou a perseguir a igreja, Rauschenbusch afirma claramente que esse poder político transnacional em oposição ao Reino de Deus tornou-se na própria personificação do mal retratado na "besta" e no "dragão" do Apocalipse.

O significado político da crença no reino satânico torna-se bastante claro na relação da Igreja primitiva com o Império Romano. O Apocalipse de João é muito esclarecedor nesse caso. O Império é claramente descrito como uma criatura e agente dos poderes satânicos. A besta de sete cabeças tinha recebido seu domínio do grande Dragão. ... Evidentemente, o sistema político de Roma e os poderes demoníacos são vistos como o lado físico e espiritual do mesmo mal (RAUSCHENBUSCH, 1917, p. 88).

Uma vez que Roma dominava sobre Judá no tempo de Cristo, e depois sobre os cristãos, Jesus teria visto a Roma perseguidora como um obstáculo para o Reino. Assim, para Rauschenbusch (1909, p. 22-23), no primeiro século, Satanás e suas hostes do mal "governavam" por meio do "opressivo, extorsivo e idólatra poder de Roma”.

Para Rauschenbusch (1911, p. 191), tragicamente, a igreja, após a queda do Império Romano, chegou a reproduzir as mesmas formas de organização 
imperial antes prevalecentes contra ela. Ele afirma que "a centralização do poder da igreja no clero e no episcopado no terceiro século" caminhava para uma reprodução da mesma "centralização do poder na organização do Império". Assim, a igreja derivou sua organização dos "moldes fornecidos por Roma Imperial”, e quando esse molde foi quebrado e desintegrado na queda do Império, "a igreja ergueu-se em seu sistema de governo como uma duplicação eclesiástica do Império", tornando-se ela mesma num empecilho para o Reino. Então, Rauschenbusch (1917, p. 89) reaplica à Igreja cristã medieval os mesmos símbolos apocalípticos descritivos do Império Romano:

Na idade Média, quando o Império Romano tinha se tornado apenas numa memória, o papado se tornou o grande poder internacional, rico, arrogante, luxurioso, dominador, comandando as forças policiais dos estados para propósitos coercitivos, e reivindicando ser herdeiro dos impérios. Os movimentos democráticos que emergiram durante os séculos 11 e 12 e se inclinaram na direção de uma religião mais livre e uma mais fraterna vida social, encontraram no papado uma força opositora.

Assim, dentro de sua própria organização, a igreja estava muito longe de viver de acordo com os princípios do Reino de Deus. "Ela se tornou uma réplica do Império Romano no qual fora moldada a sua organização. Os papas fizeram o seu melhor para copiar os Césares de quem eles herdaram o trono" (RAUSCHENBUSCH, 1914, p. 81). Nesse contexto, segundo ele, o Apocalipse recebeu um novo fôlego de vida. Para os seguidores de Cristo, "a cidade sobre os sete montes, embriagada com o sangue dos santos e vestida em escarlate, estava ainda ali". Eles "sofreram sob o punho dessa hierarquia internacional" e não viram esse poder como uma igreja usando medidas opressivas, mas como "um poder anticristão, o instrumento de Satanás e adversário de Deus”. Rauschenbusch (1917, p. 89) afirma, então, que "essa crença foi herdada pelo protestantismo e foi uma de suas armas de combate". Mais uma vez, uma realidade política e social atribuiu "calor e vitalidade à crença no reino de Satanás".

Rauschenbusch (1917, p. 89) entende que "a crença num reino satânico do mal" deriva sempre seu concreto significado e vitalidade de "realidades sociais e políticas", e esta foi a interpretação dos "seguidores de Cristo" na Idade Média e dos protestantes depois deles. "Esta interpretação foi tão útil ao longo da batalha do Protestantismo com o Romanismo que ela adquiriu um tipo de autoridade canônica" (RAUSCHENBUSCH, 1911, p. 
O reino Norte-Americano: a escatologia do Evangelho 135 Social de Rauschenbusch e o Destino Manifesto

109). Assim, o teólogo de Rochester (1917, p. 215) entende que o contexto histórico da escatologia é sempre influenciado por causas sociais. "Algumas partes da escatologia têm sido vivificadas, outras modificadas e algumas ainda fadadas ao esquecimento pela pressão das causas sociais". De forma que "um apocalipse condicionado historicamente conhece novas condições históricas na escatologia do Evangelho Social” (SMUCKER, 1994, p. 72).

Rauschenbusch (1917, p. 89) afirma ainda que "hoje não há um tal poder global opressivo como o Império Romano ou o papado medieval", e assim não há mais espaço para uma crença num reino demoníaco. Contudo, ele via seu tempo como um período decisivo para o Reino ou para o juízo divino sobre a nação, cujo poder era capaz de atuar pelo estabelecimento do Reino, caso ela fosse infiel à sua missão. Assim, ele suplica a Deus que salve os Estados Unidos a fim de que esse país não seja "tragado pela culpa mais profunda" dos pecados de "homens sem visão e que não conhecem outra coisa senão a luxúria". Numa menção ao tempo do juízo, previsto no Apocalipse, ele (1909, p. 102, grifos do autor) diz: "Ajuda-nos com mãos limpas a romper a rede que eles [homens egoístas] teceram sobre nós e a conduzir nosso povo de volta para a tua lei, para que a marca da besta permaneça fora da mão direita e da fronte de nossa nação e nossos pés não sejam postos no caminho descendente para as trevas das quais não há jamais retorno".

Considerando sua visão acerca da trajetória histórica do Império Romano e do papado, em sua chance perdida de contribuir para o estabelecimento do Reino, Rauschenbusch parece aplicar a mesma condição aos Estados Unidos. Para ele, se falharem em sua missão relativa ao Reino, os Estados Unidos estariam sob a "marca da besta", a exemplo dos poderes imperiais anteriores. Isto é, essa nação se tornaria um poder opressor e oposto ao Reino em vez de um instrumento do mesmo, recebendo merecidamente a "marca da besta". Nesse tempo crucial, revestido de urgência, Rauschenbusch (1909, p. 82) diz: "Necessitamos de nova luz e uma nova mensagem" e do "antigo espírito de profecia”, os quais só Deus pode conceder. Numa linguagem mais escatológica ainda, ele afirma que o povo de Deus na terra está "temeroso" porque o "trovão da ira" de Deus está "agora escuro" sobre o céu (RAUSCHENBUSCH, 1909, p. 102). Retomando os antigos impérios, que traíram sua missão pelo Reino, ele (1909, p. 102) assevera: "Nas ruínas dos impérios mortos nós temos visto como tu [Deus] pisaste o lagar da tua ira quando a medida da iniquidade deles estava cheia", o que pode se repetir novamente. 
Rauschenbusch, dessa forma, expressa a convicção de viver num tempo decisivo em que o Reino de Deus ou a perda do mesmo, com o consequente juízo, parecia estar às portas. No entanto, se a nação norteamericana entendesse sua oportunidade de empregar seus recursos materiais e humanos segundo o plano divino, o Reino poderia crescer e se expandir para o mundo, num processo gradativo de democratização e cristianização de todos os povos.

\section{Considerações finais}

A leitura dos textos de Rauschenbusch permite enxergar certos pontos de conexão entre seu pensamento social e a ideologia do Destino Manifesto. Como um sistema da cultura, o chamado "messianismo norte-americano" permeia o texto de diversos pensadores como uma visão de mundo, na qual os Estados Unidos são vistos como uma nação eleita por Deus para um papel excepcional na História. Expressões e conceitos fundadores como "liberdade", "caminho ocidental da esperança", "nossa nação", "nação dedicada à liberdade", "cidade sobre a colina" e "guardador de nosso irmão" entrecruzam os textos da cultura norte-americana e permitem considerar o Evangelho Social de Rauschenbusch como uma versão mais cristianizada dos ideais revolucionários norte-americanos.

No entanto, é preciso considerar que Rauschenbusch não reproduz simplesmente o ideário do Destino Manifesto, mas o expande ao atribuir à nação norte-americana um papel claro como precursora do Reino, como instrumento para cristianizar o mundo, segundo o modelo da revolução social iniciada por Jesus. Ao mesmo tempo, ele adverte para a possibilidade iminente de se perder essa vocação e de seguir na mesma direção da queda social e religiosa dos impérios anteriores. Caso deixe de exercer seu papel profético em promover o Reino de Deus na terra, os Estados Unidos deixariam de ser uma nação escolhida para ser um instrumento do mal em oposição aos ideais do mesmo Reino.

Ao advertir da possibilidade da "marca da besta" sobre a nação norte-americana, no iminente juízo divino, em seu tempo, Rauschenbusch deixa claro que a eleição celestial e vocação divina implicam tremendas responsabilidades. Os resultados da atuação do poder global norteamericano no mundo em termos de promoção ou negação da liberdade, da justiça e da igualdade de todos os povos servem como um referencial para se avaliar que caminho a nação norte-americana de fato tem tomado 
em relação aos ideais do Reino de Deus enfatizados pelo Evangelho Social de Walter Rauschenbusch.

\section{Referências}

ARMSTRONG, K. The Battle for God: A History of Fundamentalism. New York: Ballantine Books, 2000.

BACON, F. A nova Atlântida. Os Pensadores. São Paulo: Nova Cultural, 1999.

BAWER, B. Stealing Jesus: How Fundamentalism Betrays Christianity. New York: Three Rivers Press, 1997.

BELLAH, R. N. The Broken Covenant: American Civil Religion in Time of Trial. Chicago: University of Chicago Press, 1992.

BULKELEY, P. A city set upon a hill. Encyclopedia Britannica. The Annals of America. Chicago: Mortimer J. Adler, 1968.

COHN, N. Na senda do milênio. Lisboa: Presença, 1981.

COLOMBO, C. Diários da descoberta da América. Floresta, RS: L\&PM, 1998.

DORNELES, V. A mitologia do império: semiótica, cultura e cinema. Curitiba: Editora CRV, 2011.

DORRIEN, G. Social Ethics in the Making: Interpreting American Tradition. Malden, MA: Blackwell, 2011.

ELIADE, M. O mito do eterno retorno. Lisboa: Edições 70, 2000.

FISHBURN, J. F. The Fatherhood of God and the Victorian Family. Philadelphia: Fortress Press, 1981.

JOHnson, J. A. (Org.). Reforming America: A Thematic Encyclopedia and Document Collection of the Progressive Era. Santa Barbara, CA: ABC-CLIO, 2017.

JUNQUEIRA, M. A. Estados Unidos: a consolidação da nação. São Paulo: Contexto, 2001.

LEMASTERS, P. Discipleship Between Creation and Redemption. New York: University Press of America, 1997.

LENS, S. A fabricação do império americano: Da Revolução ao Vietnã. Rio de Janeiro: Civilização Brasileira, 2006.

LOTMAN, I. A estrutura do texto artístico. Lisboa: Estampa, 1978.

LOTMAN, I. La semiosfera: semiótica de la cultura e del texto. Tradução de D. Navarro. Vol. I. Frónesis Cátedra: Universitat de Valencia, 1996.

LOTMAN, I. La semiosfera: semiótica de las artes y de la cultura. Tradução de D. Navarro. Vol. III. Frónesis Cátedra: Universitat de Valencia, Madrid, 2000. 
OVASON, D. The Secret Symbols of Dollar Bill. New York: Perenial Currents, 2004.

PELIKAN, J. The Christian Tradition: A History of the Development of Doctrine. Vol. 5. Chicago: Chicago University Press, 1989.

RAUSCHENBUSCH, W. A Theology for the Social Gospel. New York: Abingdon Press, 1917.

RAUSCHENBUSCH, W. Christianity and the Social Crisis. New York: McMilliam, 1911.

RAUSCHENBUSCH, W. Christianizing the Social Order. New York: McMilliam, 1914.

RAUSCHENBUSCH, W. For God and the People: Prayers of the Social Awakening. New York: Pilgrim Press, 1909.

SANDERS, B. Walter Rauschenbusch on Society. In: TORRE, M. A., e THOMAS, S. M. F. (Orgs.). Beyond the Pale: Reading Ethics from the Margins. Louisville, KT: Westminster John Knox Press, 2011.

SMUCKER, D. E. The Origins of Walter Rauschenbusch Social Ethics. Londres: McGillQueen's University Press, 1994.

STRONG, J. Our Country: Its Possible Future and its Present Crisis. New York: Baker and Taylor Company, 1891.

TUVESON, E. L. Redeemer Nation: The Idea of America's Millenial Role. Chicago: University of Chicago Press, 1980.

Submetido em: 14-8-2017

Aceito em: 16-8-2018 